\title{
Macrophage Function and the Role of GSK3
}

\author{
Sarvatit Patel ${ }^{1,2}$ and Geoff H. Werstuck 1,2,3,*(D) \\ 1 Thrombosis and Atherosclerosis Research Institute, 237 Barton Street E, Hamilton, ON L9L 2X2, Canada; \\ sarvatit.patel@taari.ca \\ 2 Department of Chemistry and Chemical Biology, McMaster University, 1280 Main St W, \\ Hamilton, ON L8S 4L8, Canada \\ 3 Department of Medicine, McMaster University, 1280 Main St W, Hamilton, ON L8S 4L8, Canada \\ * Correspondence: geoff.werstuck@taari.ca; Tel.: +1-905-521-2100 (ext. 40747)
}

check for updates

Citation: Patel, S.; Werstuck, G.H. Macrophage Function and the Role of GSK3. Int. J. Mol. Sci. 2021, 22, 2206. https://doi.org/10.3390/ijms22042206

Academic Editor: Michael Henein

Received: 6 February 2021

Accepted: 19 February 2021

Published: 23 February 2021

Publisher's Note: MDPI stays neutral with regard to jurisdictional claims in published maps and institutional affiliations.

Copyright: (c) 2021 by the authors. Licensee MDPI, Basel, Switzerland. This article is an open access article distributed under the terms and conditions of the Creative Commons Attribution (CC BY) license (https:/ / creativecommons.org/licenses/by/ $4.0 /)$.

\begin{abstract}
Macrophages are present in nearly all vertebrate tissues, where they respond to a complex variety of regulatory signals to coordinate immune functions involved in tissue development, metabolism, homeostasis, and repair. Glycogen synthase kinase 3 (GSK3) is a ubiquitously expressed protein kinase that plays important roles in multiple pathways involved in cell metabolism. Dysregulation of GSK3 has been implicated in several prevalent metabolic disorders, and recent findings have highlighted the importance of GSK3 activity in the regulation of macrophages, especially with respect to the initiation of specific pathologies. This makes GSK3 a potential therapeutic target for the development of novel drugs to modulate immunometabolic responses. Here, we summarize recent findings that have contributed to our understanding of how GSK3 regulates macrophage function, and we discuss the role of GSK3 in the development of metabolic disorders and diseases.
\end{abstract}

Keywords: macrophage function; glycogen synthase kinase (GSK)-3; molecular mechanisms; inflammatory response; atherosclerosis

\section{Macrophages}

Macrophages are the first line of defense in the innate immune system. While most macrophages differentiate from circulating monocytes, a distinct embryonically derived population of resident macrophages exists in many tissues, including the heart, lung, and liver [1]. Macrophages play versatile phagocytic, endocytic, and secretory roles as a central part of the maintenance of tissue homeostasis [2], wound healing [3], muscle regeneration [4], and limb regeneration [5] (Figure 1). In response to chemotactic signals, they migrate toward sites of inflammation, where they ingest and degrade cell debris and orchestrate inflammatory responses. Macrophage function is dysregulated in several diseases, including tuberculosis [6], chikungunya [7], cardiovascular disease [8], HIV infection [9], cancer [10], and obesity [11].

Tissue-specific macrophage activity is regulated by microenvironmental stimuli that direct distinct transcriptional programming to modulate macrophage function [12]. There are three broad groups of receptors that are particularly relevant for macrophage activation (Figure 1): (i) receptors coupled to the nuclear factor kappa-light-chain-enhancer of activated B cells (NF-KB) and activator protein 1 (AP-1) family of transcription factors, which regulate most inflammatory genes; (ii) receptors coupled to signal transducer and activator of transcription (STAT) family transcription factors; and (iii) nuclear receptors (NR) regulating transcriptional activity [12]. Signaling through these pathways determines macrophage polarization and phenotype.

Macrophages can be polarized into several different subtypes that have distinct characteristics/functions. The extreme phenotypes are pro-inflammatory (M1) macrophages and anti-inflammatory (M2) macrophages [13]. Pro-inflammatory macrophages can be induced by exposure to interferon-gamma (IFN $\gamma$ ) and/or lipopolysaccharide (LPS). These 
macrophages play an important role early in a crisis by mobilizing a response to localized injury. Pro-inflammatory macrophages express transcription factors such as NF- $\mathrm{kB}$, AP-1, STAT1, and interferon regulatory factor (IRF)-5, which leads to increase secretion of inflammatory cytokines including tumor necrosis factor (TNF)- $\alpha$, interleukin (IL)- $1 \beta$, IL-6, and IL-12 [13]. This amplifies the inflammatory response and directs host-defenses against invading pathogens. Anti-inflammatory, or alternatively activated, macrophages can be induced by exposure to IL-4 or IL-13. Alternatively, activated macrophages produce anti-inflammatory cytokines, including IL-10 and transforming growth factor (TGF)$\beta$ [13]. These anti-inflammatory macrophages are important for resolving inflammation, initiation of tissue repair, and return to tissue homeostasis [14]. There are two main groups of anti-inflammatory macrophages, regulatory macrophages, and wound-healing macrophages [15]. Regulatory macrophages facilitate the resolution of inflammation through the secretion of the immunosuppressive cytokine IL-10 [15]. The wound-healing macrophages produce IL-4 and exhibit enhanced arginase activity to produce polyamines and collagen in order to facilitate the redevelopment of the damaged tissue [15]. Several intermediate macrophage subtypes, including $\mathrm{M}_{\mathrm{ox}}, \mathrm{M}_{\mathrm{hem}}$, and $\mathrm{M}_{4}$, have been identified that each expresses a unique combination of markers [16]. The role and importance of these macrophage subtypes are less well understood [16]. Exogenous control over macrophage polarization may facilitate modulation of the inflammatory response and more efficient wound healing and tissue regeneration.

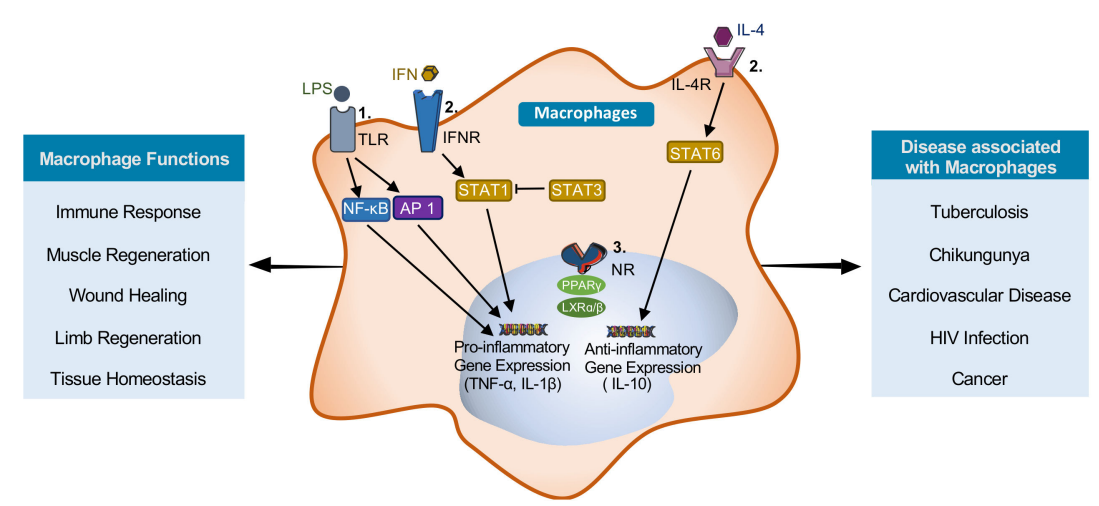

Figure 1. Macrophage: polarization, function, and associated diseases. Three main families of receptors regulate macrophage polarization and function. These are (1) the toll-like receptors (TLRs) that signal through nuclear factor kappa-light-chain-enhancer of activated B cells (NFkB) and AP-1, (2) the interferon receptor (IFNR) and interleukin (IL)-4 receptors that signal through signal transducer and activator of transcriptions (STATs), and (3) the nuclear receptors. Macrophage stimulated with lipopolysaccharide (LPS) and/or interferon-gamma (IFN $\gamma$ ) polarize to pro-inflammatory (M1) macrophages. Stimulation with IL4 induce polarization to anti-inflammatory (M2) macrophages. Regulation is important for proper physiological responses; however, dysregulation can contribute to the pathogenesis of diseases.

\section{Glycogen Synthase Kinase 3}

GSK3 is a serine/threonine kinase that plays a central role in several pathways that regulate cell metabolism, proliferation, and viability [17]. There are two ubiquitously expressed forms of GSK3 in mammals (GSK3 $\alpha(51 \mathrm{kDa})$ and GSK3 $\beta(47 \mathrm{kDa}))$, as well as the GSK3 $\beta$ splice variant, GSK3 $\beta 2$, which is expressed primarily in the central nervous system [18]. Isoforms GSK3 $\alpha$ and GSK3 $\beta$ are $98 \%$ homologous within the kinase domain and appear to possess both overlapping and unique functions [19]. Over one hundred putative substrates for GSK3 $\alpha / \beta$ have been identified [20]; however, the physiological relevance of most of these is not known.

Whole-body GSK3 $\alpha$-deficient mice are viable and develop normally with very mild or no overt phenotype [21]. Genetic deletion of GSK3 $\beta$ results in severe hepatic and cardiac abnormalities during development leading to embryonic lethality [22,23]. Recent evidence 
suggests that GSK3 $\alpha$ and GSK3 $\beta$ play unique and independent roles in skeletal muscle cell insulin signaling [24-26], cardiomyocyte development and proliferation [19], and Th cell polarization [26]. GSK3 $\alpha / \beta$ also plays a role in a variety of biological processes, including glycogen metabolism, inflammatory response, migration, proliferation, protein translation, $\mathrm{T}$ cell activation, and apoptosis (Figure 2) [17].

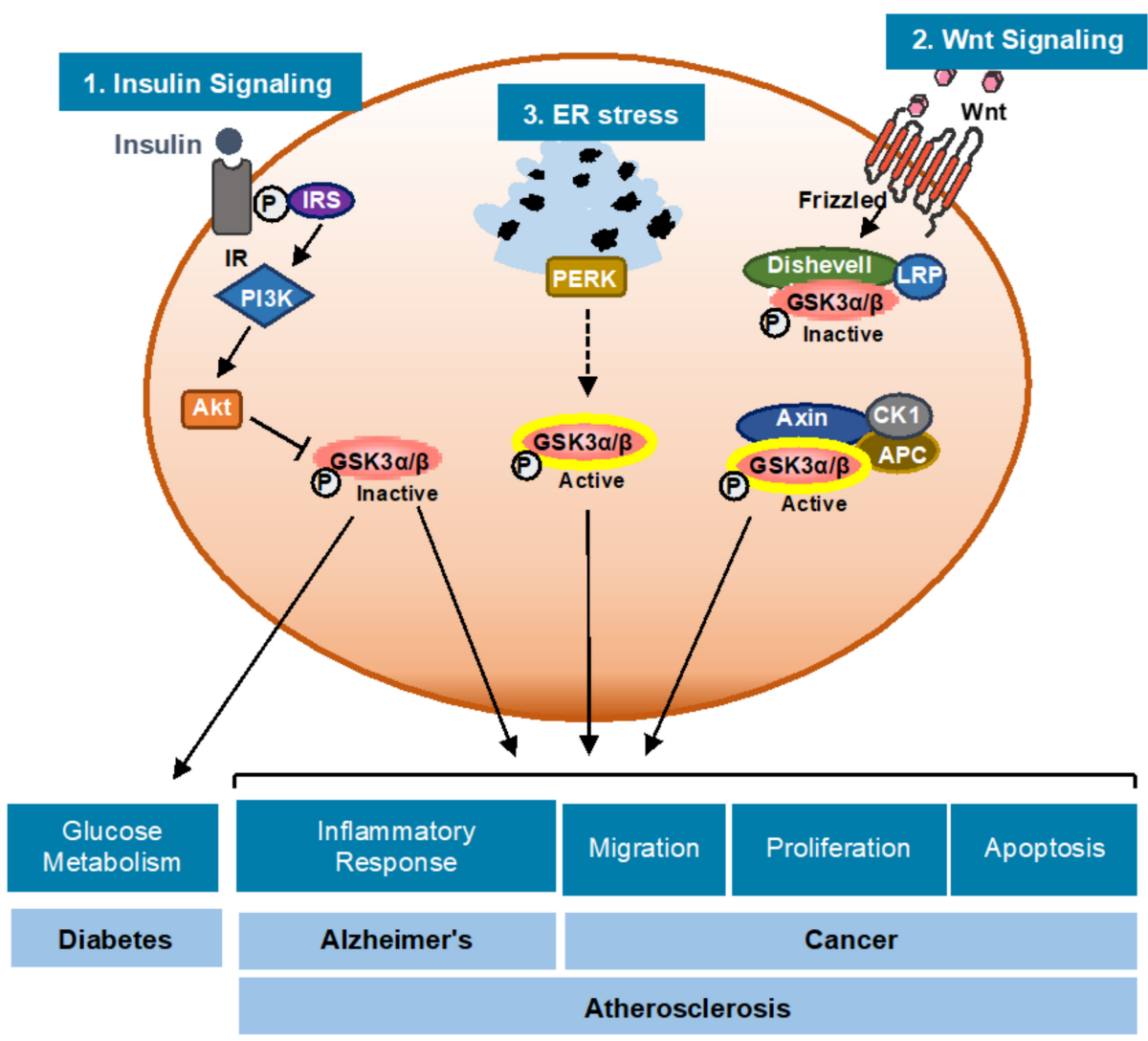

Figure 2. GSK3 $\alpha / \beta$ : regulation, cellular functions and diseases. Three cellular signaling pathways are directly involved in GSK3 $\alpha / \beta$ regulation: (1) insulin binds to the insulin receptor and activates the PI3-Akt pathway leading to GSK3 $\alpha / \beta$ inhibition; (2) endoplasmic reticulum stress (ER stress) signaling and/or unfolded protein response (UPR) activation promotes the activation of GSK $3 \alpha / \beta$ through the endoplasmic reticulum kinase (PERK) pathway; and (3) Wnt ligands bind to the Frizzled receptor and induces the formation of a complex of the scaffold protein axin, APC, CK1 and the kinase Dishevelled, which phosphorylates and inactivates GSK $3 \alpha / \beta$. The complex interplay between these pathways regulates the network of signaling pathways that modulate cell viability and metabolism.

GSK $3 \alpha / \beta$ is an atypical kinase as it is usually found in a constitutively active state. It is well established that signaling through the insulin and Wnt pathways inhibit GSK $3 \alpha / \beta$ activity $[20,27]$. A recent study from our lab shows that the presence of endoplasmic reticulum stress (ER stress) in Thp-1 macrophages activates the protein kinase R-like endoplasmic reticulum kinase (PERK) signaling branch of the unfolded protein response (UPR) to promote GSK3 $\alpha / \beta$ activity [28]. The mechanism underlying this effect is still being delineated. GSK $3 \alpha / \beta$ activity is predominantly regulated by phosphorylation (Figure 2). Autophosphorylation of tyrosine (Tyr) 279 or Tyr216 is required for activation of GSK3 $\alpha$ and GSK3 $\beta$, respectively [17]. Protein kinase B (PKB/Akt) [29], PKA [30], and MAP kinase activated protein (MAPKAP) kinase-1 (p90rsk) $[31,32]$ inhibit GSK3 $\alpha / \beta$ by phosphorylation of serine (Ser) 21 of GSK $3 \alpha$ and Ser9 of GSK3 $\beta$. Protein phosphatase (PP) 1 dephosphorylates Ser21/9 of GSK3 $\alpha / \beta$ and increases GSK3 $\alpha / \beta$ activity [20].

GSK $3 \alpha / \beta$ is also regulated through the formation of distinct protein complexes. GSK3 $\beta$ forms complexes with axin, adenomatous polyposis coli (APC), casein kinase 1 
(CK1), and $\beta$-catenin, which facilitate the phosphorylation of $\beta$-catenin at Thr41, Ser37, and Ser33, leading to its ubiquitylation and degradation [20,27]. Wnt signaling inhibits this complex of proteins, which leads to changes in cellular functions such as cell growth, survival, and differentiation $[27,28]$. p38MAPK phosphorylates Ser9 of GSK3 $\beta$ and regulates the canonical Wnt- $\beta$-catenin signaling pathway [33]. GSK3 $\alpha / \beta$ mainly resides in the cytoplasm but it is also present in mitochondria and the nucleus, as well as other subcellular compartments, where it can be regulated by localized signaling activities $[20,27,34,35]$.

GSK3 $\alpha / \beta$ has been linked to several disorders and diseases, including cancer [36], bipolar mood disorder [37], diabetes [38], Alzheimer's disease [39], and atherosclerosis [40] (Figure 2). Because of its involvement in a great number of signaling pathways and several disease processes, it is important to better understand the role and regulation of GSK3 $\alpha / \beta$ in different cellular pathways and functions.

Evidence suggests that GSK $3 \alpha / \beta$ plays a central role in a variety of different signaling pathways that are relevant to macrophage function including polarization [41-44], inflammatory response [45-57], unfolded protein response [28,40-43], glucose [58-61] and lipid [28,62] metabolism, viability $[17,28,63-65]$, migration [66-68], and proliferation [69-72] (Figure 3). Here, we summarize the current literature on the role of GSK3 $\alpha / \beta$ in regulating specific macrophage functions.

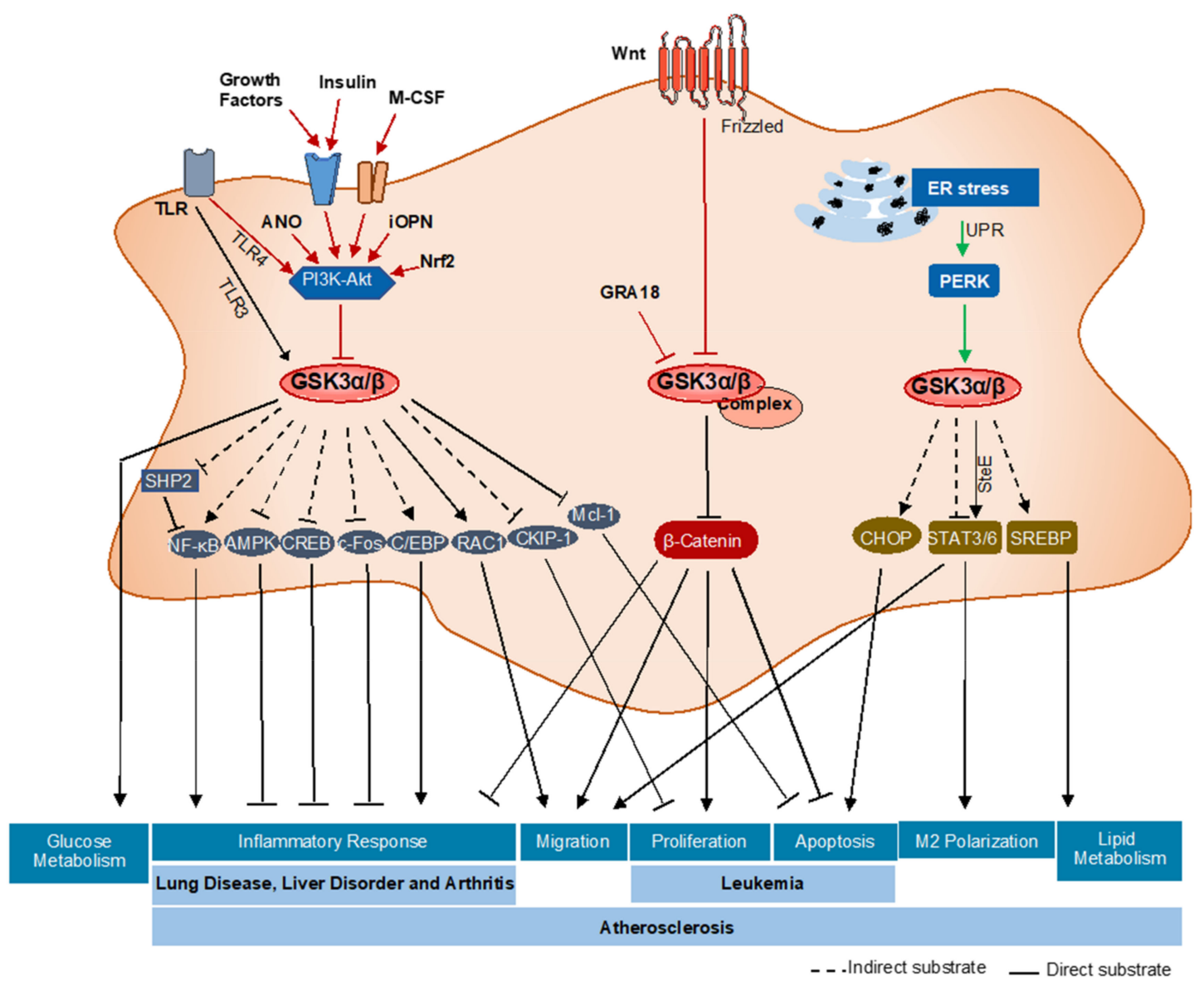

Figure 3. A summary of the GSK $3 \alpha / \beta$ signaling pathways in macrophage functions and related diseases. In macrophages GSK $3 \alpha / \beta$ can be activated or inactivated by different upstream signaling pathways. GSK $3 \alpha / \beta$ has a large number of downstream substrates that regulate a variety of different downstream signaling pathways to control macrophage phenotype and function. Dysregulation of one or more of these pathways has been implicated in the development of several different disorders/diseases. 


\section{GSK $3 \alpha / \beta$-Regulation of Macrophage Function \\ 3.1. Macrophage Polarization}

In response to various exogenous stimuli, macrophages can polarize into different subtypes, thereby adopting altered functional programs. Polarization pathways are regulated by JAK-STAT signaling (Figure 1). STAT1 is the key transcription regulator for M1 macrophage polarization, whereas STAT3 and STAT6 regulate M2 macrophage polarization [41]. Recent evidence suggests that GSK3 $\alpha / \beta$ modulates macrophage polarization by directly and/or indirectly affecting STAT phosphorylation [42].

Using bone-marrow-derived macrophages (BMDM) from myeloid-specific GSK3 $\alpha$ and/or GSK3 $\beta$ knock out mice, we have shown that GSK3 $\alpha$ specifically regulates STAT3 and STAT6 phosphorylation/activation. Myeloid-specific GSK3 $\alpha$ knockout resulted in increased phosphorylation at Tyr705 of STAT3 in M1 macrophages as well as increased phosphorylation at Tyr641 of STAT6 in M2 macrophages [43]. This suggests that GSK3 $\alpha$ actively suppresses STAT3/ 6 phosphorylation to promote M1 polarization.

The salmonella effector (SteE) protein has been shown to alter the substrate and amino acid specificity of GSK3 $\alpha$ and $\beta$ so that they directly phosphorylate Tyr705 of STAT3. This results in STAT3 activation and promotes M2 macrophage polarization [44]. To date, no mammalian equivalent of SteE has been identified.

\subsection{Inflammatory Response}

Macrophages accumulate at sites of injury and participate in the innate immune response, which can be either pro-inflammatory or anti-inflammatory [14]. Several signaling pathways associated with the inflammatory response are known to be regulated by GSK3 $\alpha / \beta$ activity [45-48]. GSK3 $\alpha / \beta$ plays a role in Toll-like receptor (TLR)-mediated pro-and anti-inflammatory cytokine production. Specifically, inhibition of GSK3 $\alpha / \beta$ results in increased production of anti-inflammatory cytokine (IL-10) and a decrease in pro-inflammatory cytokine (IL-1 $\beta$, IL-6, TNF- $\alpha$, and IL-12) production by human peripheral blood mononuclear cells (PBMCs) [45]. A recent review of the role of GSK3 $\beta$ in TLR signaling suggests that GSK3 $\beta$ negatively regulates TLR4-mediated pro-inflammatory cytokine (IFN- $\beta$ ) production [46] and interacts with TRAF3 to act as a positive regulator for TLR3-mediated pro-inflammatory cytokine (IFN- $\beta$ ) production [47]. Cellular growth factors, including insulin, stimulate the class I PI 3-Kinases (PI3K) and activate Akt, which phosphorylates GSK3 $\alpha / \beta$ resulting in its inhibition [48]. Inhibition of GSK3 $\beta$ by PI3K-Akt leads to an increase in IL-10 and IL-12 production [45]. Other data suggest that intracellular osteopontin (iOPN) regulates GSK3 $\beta$ and 4EBP1 phosphorylation via the PI3K-Akt signaling pathway to decrease TLR4-mediated inflammatory responses [49]. Adenosine N1-oxide (ANO) also activates the PI3K-Akt signaling pathway, leading to inhibitory phosphorylation of GSK3 $\beta$, which results in a decrease in TLR4 mediated pro-inflammatory responses and upregulation of anti-inflammatory transcription factor (c-Fos) [50]. Furthermore, inhibition of GSK3 $\beta$ by the ANO-PI3K-Akt pathway leads to an increase in the binding of cAMP response element-binding protein (CREB) to nuclear coactivator CREBbinding protein (CBP), which results in suppression of the binding of NF- $\mathrm{kB}$ p65 to CBP [50]. Together, these data support a role for GSK3 $\beta$ in the TLR4 mediated immune response.

GSK $3 \alpha / \beta$ activity affects several transcription factors that regulate cytokine expression and inflammatory responses $[51,52]$. GSK3 regulates NF- $\mathrm{KB}$ function as GSK3 $\beta$ deficient embryos showed reduced NF- $\mathrm{KB}$ function [22]. TNF- $\alpha$ regulates GSK3 $\alpha / \beta$ signaling to promote feedback inhibition of NF- $\mathrm{kB}$, which leads to reduced inflammatory cytokine production [53]. GSK3 $\beta$ inhibits $5^{\prime}$ AMP-activated protein kinase (AMPK) activation and Src homology-2 domain-containing phosphatase (SHP) induction to promote the pro-inflammatory response [54]. Furthermore, this immune regulatory mechanism was independent of PI3K-Akt signaling and GSK3 $\beta$ phosphorylation [55]. GSK3 $\beta$ inhibits SHP2, which indirectly facilitates IFN $\gamma$-induced phosphorylation of Ser536 of NF-kB and activation [56]. Another study suggests that GSK3 $\alpha / \beta$ inhibition significantly reduces DNA binding of CCAAT-enhancer-binding proteins (C/EBP) and increases IL-10/IL-12 
production in granulocyte-macrophage/dendritic cells (GM/DCs) [57]. The parasite-dense granule protein GRA18 forms a complex with GSK3 $\alpha / \beta$ and PP2A-B56 in the cytoplasm, which drives $\beta$-catenin accumulation and increases chemokine (C-C motif) ligand (CCL) 17 and CCL22 chemokine production, leading to an increase in the anti-inflammatory response [57]. In summary, GSK3 $\alpha / \beta$, directly and indirectly, regulates the inflammatory response in macrophages. The downstream substrate(s) that link GSK $3 \alpha / \beta$ and these factors require further investigation to better understand the relevant signaling pathways.

\subsection{Unfolded Protein Response}

In response to ER stress, macrophages activate the UPR to maintain ER homeostasis. Evidence from our lab and others has shown that ER stress can induce GSK $3 \alpha / \beta$ activity $[28,40]$. ER stress signaling through GSK3 $\alpha / \beta$ is dependent upon the PERK branch of the UPR. ER stress-GSK3 $\alpha / \beta$ signaling appears to regulate downstream pathways involving apoptosis/viability, polarization, and lipid accumulation [28,43]. The mechanisms by which PERK promotes GSK3 $\alpha / \beta$ are still unknown and require further investigation.

\subsection{Glucose Metabolism}

GSK $3 \alpha / \beta$ was named for its role in regulating glycogen synthesis/metabolism. Whereas anti-inflammatory macrophages rely predominantly on oxidative phosphorylation for energy production, pro-inflammatory macrophages rely on the glycolytic pathway. The regulation of glucose metabolism in the inflammatory response is not fully understood. The nuclear factor erythroid 2-related factor 2 (Nrf2) is a transcription factor that coordinates glucose metabolism to stress responses, and specifically upregulates antioxidant response elements in conditions of oxidative stress [58-60]. Genetic Nrf2 knockout in M1 macrophages downregulates the expression of Akt and thereby reduces the inhibitory phosphorylation of GSK3 $\beta$. Active GSK3 $\beta$ directly promotes the inhibition of glycogen synthase and reduces glycogenesis [61].

\subsection{Lipid Accumulation/Metabolism}

Lipid metabolism plays a critical role in the function of both pro-and anti-inflammatory macrophages [62]. In particular, anti-inflammatory macrophages display enhanced mitochondrial oxidative phosphorylation (OXPHOS) [62]. During atherogenesis, macrophages can accumulate lipids and become foam cells. A previous study from our lab suggests that pharmacological inhibition of GSK3 $\alpha / \beta$ attenuates the expression of genes regulating lipid and cholesterol biosynthesis, including fatty acid synthase (FAS), sterol regulatory element-binding proteins (SREBP)-1c, SREBP-2, and 3-hydroxy-3-methylglutarylCoA (HMG-CoA) [28]. Furthermore, inhibition of GSK3 $\alpha / \beta$ in vivo blocks the ability of macrophage foam cells to accumulation lipid and attenuates atherogenesis [28]. The role of GSK3 $\alpha / \beta$ in reverse cholesterol transport is still unknown and requires further investigation.

\subsection{Apoptosis}

GSK3 $\alpha / \beta$ has previously been shown to play a role in regulating cell viability [17]. Data from our lab and others suggest that GSK $3 \alpha / \beta$ plays a pro-apoptotic role in cells. GSK $3 \alpha / \beta$ inhibition decreases the expression of the pro-apoptotic C/EBP homologous protein (CHOP) in macrophages [28]. Activated GSK3 $\alpha / \beta$ phosphorylates myeloid cell leukemia (Mcl)-1, resulting in Mcl-1 degradation followed by apoptosis [63]. In U937 cells (an acute myeloid leukemia cell line), a complex of N-Myc downstream-regulated gene 2 (NDRG2), GSK3 $\alpha / \beta$, and PP2A is formed upon treatment with the anti-cancer drug As2O3 [64]. This leads to GSK3 $\alpha / \beta$ activation through dephosphorylation at Ser9 by PP2A, followed by Mcl-1 degradation and apoptosis [65]. In alveolar macrophages, LPS-induced apoptosis occurs by activation of the Wnt pathway followed by destabilization of GSK3 $\beta$ and accumulation of phospho-Ser9-GSK3 $\beta$ and $\beta$-catenin [65]. These data suggest that GSK $3 \alpha / \beta$ indirectly activates CHOP and directly phosphorylates $\beta$-catenin and Mcl- 1 to allow macrophages to undergo apoptosis. 


\subsection{Migration}

The ability of macrophages to move is central to their role in the innate immune system. Macrophage movement is essential for the phagocytosis of foreign material and apoptotic cells. Studies have shown that in obese visceral adipose tissue (VAT), GSK3 inhibition reverses obesity-induced inflammation via reducing apoptosis inhibitor of macrophage (AIM) levels to attenuate macrophage/monocyte migration and macrophage accumulation [66]. In LPS stimulated macrophages, Akt inhibits GSK3 $\beta$, which leads to $\beta$-catenin accumulation. This activates matrix metalloproteinase (MMP)-9 gene induction and promotes cell migration [67]. Inhibition of GSK3 $\beta$ affects integrin signaling via reduced Ras-related C3 botulinum toxin substrate (RAC)-1 activity, thereby affecting the activation of cofilin and actin rearrangement. These activities lead to a decrease in lamellipodia formation, adhesion, and migration of monocytes, thereby preventing monocyte migration across brain endothelial cells [68]. In summary, GSK $3 \alpha / \beta$ signals through STAT, $\beta$-catenin, and $\mathrm{RAC1}$ to regulate macrophage migration.

\subsection{Proliferation}

In response to inflammation, macrophages accumulate and proliferate at the injury location in the tissue. These macrophages may be recruited from the blood or be derived from resident macrophages. Macrophage colony-stimulating factor (M-CSF) signals through PI3K-Akt to inhibit GSK3 $\beta$, resulting in casein kinase 2 interacting protein-1 (CKIP-1) and $\beta$ catenin accumulation in the cytosol [69]. $\beta$-catenin promotes the expression of proliferation genes such as cyclin D and c-Myc. CKIP-1 inhibits TNF receptor associated factor (TRAF) 6-mediated Akt activation, acting as a negative feedback loop [69]. PI3K/Akt/GSK3 signaling has been shown to play a central role in the proliferation of Anthrax lethal toxin (LeTx)-induced macrophages [70]. GSK3 $\beta$ inhibitors suppress cell growth and induce apoptosis in different leukemia cell lines including acute myeloid leukemia (AML) [71]. Ceramide 1-phosphate (C1P) upregulates the expression of two major downstream targets of GSK3 $\beta$, cyclin D1 and c-Myc, which regulate cell proliferation [72]. C1P triggered rapid phosphorylation of PI3K-Akt, which induces GSK3 $\beta$ inhibition, leads to an increase in macrophage proliferation [72]. These data indicate that GSK3 $\alpha / \beta$ phosphorylates $\beta$ catenin and regulates proliferation-related genes such as cyclin D and c-Myc to control macrophage proliferation.

In summary, GSK $3 \alpha / \beta$ activity is positively regulated by the upstream ER stressPERK pathway. Other upstream signaling factors, including ANO, GRA18, Wnt signaling pathway, and the insulin-PI3K-Akt pathway, led to GSK $3 \alpha / \beta$ inactivation in macrophages. GSK $3 \alpha / \beta$ signals through downstream effector proteins, including Glut4, STAT, NF- $\mathrm{kB}$, CREB, C/EBP, Mcl-1, $\beta$-catenin, CHOP, Mcl-1, SREBP, and RAC1, to regulate a variety of functions in macrophages.

\section{Diseases Associated with Macrophage Dysfunction and GSK3 $\alpha / \beta$}

GSK $3 \alpha / \beta$ activity has been implicated in the pathogenesis of several different metabolic diseases and disorders. Therefore, it is important to understand the specific roles of GSK $3 \alpha / \beta$ and the therapeutic potential of specific interventions to target this factor (Figure 3).

In vivo studies show that inhibition of GSK3 $\beta$ decreases production of TNF- $\alpha$ and macrophage inflammatory protein (MIP)-2 as well as the release of the alarmins high mobility group box (HMGB)-1 and histone 3 in the lungs, perhaps reducing the severity of LPS-induced lung injury [73]. These results show that GSK3 $\beta$ plays an important contributory role in worsening the severity of acute lung injury (ALI). In alveolar macrophages from pulmonary fibrosis patients and mice, GSK3 $\beta$ and the ubiquitin-editing enzyme A20 regulate $C / E B P \beta$ enzymatic activity and play a role in lung fibrosis [74]. This study suggests that GSK3 $\beta$ is a potential target for treating pulmonary fibrosis and fibroproliferative lung diseases.

In bone marrow-derived macrophages, inhibition of GSK3 $\beta$ down-regulates proinflammatory gene expression including IL12, TNF- $\alpha$, and C-X-C motif chemokine (CXCL) 
10, which protect the liver against ischemia/reperfusion injury (IRI) [75]. These data suggest that GSK3 $\beta$ may be a target as a therapeutic strategy to ameliorate liver IRI.

A previous study suggests that GSK $3 \alpha / \beta$ inhibitors could be used as anti-inflammatory drugs to treat the rheumatoid arthritis (RA) [76]. Another study in a mouse model of rheumatoid arthritis shows that GSK-3 $\beta$ inhibitors suppress inflammatory responses by downregulating the NF-kB signaling pathway, along with downregulating the expression of c-Jun N-terminal kinase (JNK), c-jun, activating transcription factor (ATF) 2, and p-38 [77]. These findings suggest that the GSK3 $\beta$ may be an efficient therapeutic target for RA.

Recent studies from our lab have implicated GSK3 $\alpha$ in the progression and development of atherosclerosis [43]. Specifically, genetic ablation of myeloid GSK3 $\alpha$ attenuates the progression of atherosclerosis in low-density lipoprotein receptor (Ldlr) knockout mice [43]. These studies suggest that the specific inhibition of one isoform of GSK3 may be an effective therapeutic approach to treat atherosclerosis. Small molecule GSK3 isoformspecific inhibitors have recently been identified and tested in mouse model systems [78]. GSK3 $\alpha$-specific inhibition weakens leukemia initiation and prolongs survival in acute myeloid leukemia (AML) mouse models [78]. This study suggests the possibility of using small molecules targeting GSK3 $\alpha$ as a therapeutic tool in the treatment of atherosclerosis and AML.

In summary, the central regulatory role of GSK $3 \alpha / \beta$ in macrophage viability and immunometabolic function suggests that it may be a viable target to treat a variety of diseases and disorders related to cancer and inflammation. Currently, the therapeutic targeting of GSK3 is impeded by several factors. First, it is clear that GSK3 $\alpha / \beta$ plays a central role in many important pathways and that inhibition of these factors could have serious detrimental side effects. Second, we have a limited understanding of the specific roles of GSK3 $\alpha$ and GSK3 $\beta$ in health and disease. Third, until recently there were no small molecule inhibitors that could distinguish between GSK3 $\alpha$ and GSK3 $\beta$. The identification of specific GSK3 $\alpha$ and GSK3 $\beta$ inhibitors [78] may allow for the more precise targeting of the relevant isoform in the treatment of a specific disease or disorder in a way that limits unwanted detrimental side effects. The next few years will provide many exciting answers as these and other more specific interventions are tested.

\section{Translational Benefits}

An understanding of the role of GSK $3 \alpha / \beta$-signaling in macrophages is potentially important in the field of drug discovery and the treatment of disease. Currently, there are 31 clinical studies on GSK3 $\alpha / \beta$ taking place all over the world [79]. These are primarily focused upon the treatment of conditions and diseases ranging from cancer to neurological disorders. None of the ongoing clinical trials are specifically focused upon macrophage function or associated disease. Results from preclinical studies suggest that isoformtargeted inhibition of macrophage GSK $3 \alpha$ or GSK3 $\beta$ may be effective in the treatment of acute myeloid leukemia [78] and atherosclerosis [40,43]. Isoform-specific inhibitors will be important in future clinical trials examining efficacy in the treatment of diseases including cancer and cardiovascular diseases.

\section{Conclusions}

In this review, we have summarized the results from recent reports that address how GSK $3 \alpha / \beta$ is regulated in macrophages and how GSK3 $\alpha / \beta$ modulates different macrophage functions and related diseases. Evidence suggests that GSK $3 \alpha / \beta$ directly or indirectly affects different downstream molecules to regulate virtually all macrophage functions. More investigation is needed to fully understand all signaling pathways related to GSK $3 \alpha / \beta$ and macrophages functions. This knowledge will potentially facilitate the development and testing of new therapeutics to treat a variety of immunometabolic diseases. 
Author Contributions: G.H.W. and S.P. wrote the paper, proofread, organized figures, and gave conceptual input to the manuscript. All authors have read and agreed to the published version of the manuscript.

Funding: This research was funded by operational grants from the Canadian Institutes for Health Research (CIHR, PJT-166092) and Heart and Stroke Foundation of Canada (HSFC, G20-0029355).

Data Availability Statement: No new data were created or analyzed in this study. Data sharing is not applicable to this article.

Acknowledgments: This research was supported by operational grants from the Canadian Institutes for Health Research (CIHR, PJT-166092) and Heart and Stroke Foundation of Canada (HSFC, G200029355). GHW holds the ISTH-McMaster Chair in Thrombosis and Haemostasis Research and is supported by an HSFC Ontario Mid-Career Investigator Award.

Conflicts of Interest: The authors declare no conflict of interest.

\section{Abbreviations}

$\begin{array}{ll}\text { AIM } & \text { Apoptosis inhibitor of macrophage } \\ \text { ALI } & \text { Acute lung injury } \\ \text { AML } & \text { Acute myeloid leukemia } \\ \text { AMPK } & \text { 5' AMP-activated protein kinase } \\ \text { ANO } & \text { Adenosine N1-oxide } \\ \text { AP1 } & \text { Activator protein 1 } \\ \text { APC } & \text { Adenomatous polyposis coli } \\ \text { ATF } & \text { Activating transcription factor } \\ \text { BMDM } & \text { Bone marrow derived macrophages } \\ \text { C/EBP } & \text { CCAAT-enhancer-binding proteins } \\ \text { C1P } & \text { Ceramide 1-phosphate } \\ \text { CBP } & \text { CREB-binding protein } \\ \text { CCL } & \text { Chemokine (C-C motif) ligand } \\ \text { CHOP } & \text { C/EBP Homologous Protein } \\ \text { CK1 } & \text { Casein kinase 1 } \\ \text { CKIP-1 } & \text { Casein kinase 2 interacting protein-1 } \\ \text { CREB } & \text { Cyclic AMP response element binding protein } \\ \text { CXCL } & \text { C-X-C motif chemokine } \\ \text { ER Stress } & \text { Endoplasmic reticulum stress } \\ \text { FAS } & \text { Fatty acid synthase } \\ \text { GSK3 } & \text { Glycogen synthase kinase 3 } \\ \text { HMGB } & \text { High mobility group box } \\ \text { HMGCoA } & \text { 3-hydroxy-3-methylglutaryl-CoA } \\ \text { IFN } & \text { Interferon } \\ \text { IFNR } & \text { Interferon receptor } \\ \text { IL } & \text { Interleukin } \\ \text { IL4R } & \text { Interleukin 4 receptor } \\ \text { iOPN } & \text { Intracellular osteopontin } \\ \text { IR } & \text { Insulin receptor } \\ \text { IRI } & \text { Ischemia/reperfusion } \\ \text { IRS } & \text { Insulin receptor substrate } \\ \text { JNK } & \text { c-Jun N-terminal kinase } \\ \text { Ldlr } & \text { Low-density lipoprotein receptor } \\ \text { LeTx } & \text { Lethal toxin } \\ \text { LPS } & \text { Lipopolysaccharides } \\ \text { LRP } & \text { Lipoprotein receptor- related protein } \\ \text { LXR } & \text { Liver X receptors } \\ \text { MAPKAP } & \text { MAP kinase activated protein } \\ & \end{array}$




$\begin{array}{ll}\text { Mcl-1 } & \text { Myeloid cell leukemia 1 } \\ \text { MIP } & \text { Macrophage inflammatory protein } \\ \text { MMP } & \text { Matrix metalloproteinase } \\ \text { NDRG2 } & \text { N-Myc downstream-regulated gene 2 } \\ \text { NFkB } & \text { Nuclear factor kappa-light-chain-enhancer of activated B cells } \\ \text { NR } & \text { Nuclear receptor } \\ \text { PBMC } & \text { Peripheral blood mononuclear cells } \\ \text { PERK } & \text { Protein kinase R-like endoplasmic reticulum kinase } \\ \text { PI3K } & \text { Phosphoinositide 3-kinases } \\ \text { PKB } & \text { Protein kinase B } \\ \text { PP } & \text { Protein phosphatase } \\ \text { PPAR } \gamma & \text { Peroxisome proliferator-activated receptor gamma } \\ \text { RA } & \text { Rheumatoid arthritis } \\ \text { RAC1 } & \text { Ras related C3 botulinum toxin substrate 1 } \\ \text { Ser } & \text { Serine } \\ \text { SHP } & \text { Src homology-2 domain-containing phosphatase } \\ \text { SREBP } & \text { Sterol regulatory element-binding proteins } \\ \text { STAT } & \text { Signal transducer and activator of transcription } \\ \text { SteE } & \text { Salmonella effector } \\ \text { TGF } \beta & \text { Transforming growth factor } \\ \text { TLR } & \text { Toll-like receptor } \\ \text { TNFa } & \text { Tumor necrosis factor a } \\ \text { TRAF } & \text { TNF receptor associated factor } \\ \text { Tyr } & \text { Tyrosine } \\ \text { VAT } & \text { Visceral adipose tissue } \\ & \end{array}$

\section{References}

1. Epelman, S.; Lavine, K.J.; Randolph, G.J. Origin and functions of tissue macrophages. Immunity 2014, 41, 21-35. [CrossRef] [PubMed]

2. Uderhardt, S.; Martins, A.J.; Tsang, J.S.; Lämmermann, T.; Germain, R.N. Resident macrophages cloak tissue microlesions to prevent neutrophil-driven inflammatory damage. Cell 2019, 177, 541-555. [CrossRef] [PubMed]

3. Krzyszczyk, P.; Schloss, R.; Palmer, A.; Berthiaume, F. The role of macrophages in acute and chronic wound healing and interventions to promote pro-wound healing phenotypes. Front. Physiol. 2018, 9, 419. [CrossRef] [PubMed]

4. Robertson, T.A.; Maley, M.A.L.; Grounds, M.D.; Papadimitriou, J.M. The role of macrophages in skeletal muscle regeneration with particular reference to chemotaxis. Exp. Cell Res. 1993, 207, 321-331. [CrossRef] [PubMed]

5. Godwin, J.W.; Pinto, A.R.; Rosenthal, N.A. Macrophages are required for adult salamander limb regeneration. Proc. Natl. Acad. Sci. USA 2013, 110, 9415-9420. [CrossRef] [PubMed]

6. Guirado, E.; Schlesinger, L.S.; Kaplan, G. Macrophages in tuberculosis: Friend or foe. Semin. Immunopathol. 2013, 35, 563-583. [CrossRef]

7. Dupuis-Maguiraga, L.; Noret, M.; Brun, S.; Le Grand, R.; Gras, G.; Roques, P. Chikungunya disease: Infection-associated markers from the acute to the chronic phase of arbovirus-induced arthralgia. PLoS Negl. Trop. Dis. 2012, 6, e1446. [CrossRef]

8. Lavine, K.J.; Pinto, A.R.; Epelman, S.; Kopecky, B.J.; Clemente-Casares, X.; Godwin, J.; Rosenthal, N.; Kovacic, J.C. The macrophage in cardiac homeostasis and disease: JACC macrophage in CVD series (Part 4). J. Am. Coll. 2018, 72, 2213-2230. [CrossRef]

9. Kruize, Z.; Kootstra, N.A. The role of macrophages in HIV-1 persistence and pathogenesis. Front. Microbiol. 2019, 10, 2828. [CrossRef]

10. Ferreira, N.; Mesquita, I.; Baltazar, F.; Silvestre, R.; Granja, S. IL-17A and IL-17F orchestrate macrophages to promote lung cancer. Cell. Oncol. 2020, 43, 643-654. [CrossRef]

11. Weisberg, S.P.; McCann, D.; Desai, M.; Rosenbaum, M.; Leibel, R.L.; Ferrante, A.W. Obesity is associated with macrophage accumulation in adipose tissue. J. Clinic. Investig. 2013, 112, 1796-1808. [CrossRef]

12. Glass, C.K.; Natoli, G. Molecular control of activation and priming in macrophages. Nat. Immunol. 2016, 17, 26-33. [CrossRef] [PubMed]

13. Arango Duque, G.; Descoteaux, A. Macrophage cytokines: Involvement in immunity and infectious diseases. Front. Immun. 2014, 5, 491. [CrossRef]

14. Patel, U.; Rajasingh, S.; Samanta, S.; Cao, T.; Dawn, B.; Rajasingh, J. Macrophage polarization in response to epigenetic modifiers during infection and inflammation. Drug Discov. Today 2017, 22, 186-193. [CrossRef]

15. Mosser, D.M.; Edwards, J.P. Exploring the full spectrum of macrophage activation. Nat. Rev. Immunol. 2008, 8, 958-969. [CrossRef]

16. Colin, S.; Chinetti-Gbaguidi, G.; Staels, B. Macrophage phenotypes in atherosclerosis. Immunol. Rev. 2014, 262, 153-166. [CrossRef]

17. Maurer, U.; Preiss, F.; Brauns-Schubert, P.; Schlicher, L.; Charvet, C. GSK-3-at the crossroads of cell death and survival. J. Cell Sci. 2014, 127, 1369-1378. [CrossRef] 
18. Mukai, F.; Ishiguro, K.; Sano, Y.; Fujita, S.C. Alternative splicing isoform of tau protein kinase I/glycogen synthase kinase $3 \beta$. J. Neurochem. 2002, 81, 1073-1083. [CrossRef] [PubMed]

19. Woodgett, J.R. Molecular cloning and expression of glycogen synthase kinase-3/factor A. EMBO J. 1990, 9, 2431-2438. [CrossRef]

20. Beurel, E.; Grieco, S.F.; Jope, R.S. Glycogen synthase kinase-3 (GSK3): Regulation, actions, and diseases. Pharmacol. Ther. 2015, 148, 114-131. [CrossRef]

21. Kerkela, R.; Kockeritz, L.; MacAulay, K.; Zhou, J.; Doble, B.W.; Beahm, C.; Greytak, S.; Woulfe, K.; Trivedi, C.M.; Woodgett, J.R.; et al. Deletion of GSK-3 $\beta$ in mice leads to hypertrophic cardiomyopathy secondary to cardiomyoblast hyperproliferation. J. Clin. Investig. 2008, 118, 3609-3618. [CrossRef] [PubMed]

22. Hoeflich, K.P.; Luo, J.; Rubie, E.A.; Tsao, M.S.; Jin, O.U.; Woodgett, J.R. Requirement for glycogen synthase kinase-3 $\beta$ in cell survival and NF-kB activation. Nature 2000, 406, 86-90. [CrossRef]

23. Patel, S.; Macaulay, K.; Woodgett, J.R. Tissue-specific analysis of glycogen synthase kinase-3 $\alpha$ (GSK-3 $\alpha)$ in glucose metabolism: Effect of strain variation. PLoS ONE 2011, 6, e15845. [CrossRef]

24. Patel, S.; Doble, B.W.; MacAulay, K.; Sinclair, E.M.; Drucker, D.J.; Woodgett, J.R. Tissue-specific role of glycogen synthase kinase $3 \beta$ in glucose homeostasis and insulin action. Mol. Cell. Biol. 2008, 28, 6314-6328. [CrossRef]

25. MacAulay, K.; Doble, B.W.; Patel, S.; Hansotia, T.; Sinclair, E.M.; Drucker, D.J.; Nagy, A.; Woodgett, J.R. Glycogen synthase kinase $3 \alpha$-specific reglation of murine hepatic glycogen metabolism. Cell. Metab. 2007, 6, 29-337. [CrossRef] [PubMed]

26. Beurel, E.; Yeh, W.I.; Michalek, S.M.; Harrington, L.E.; Jope, R.S. Glycogen synthase kinase-3 is an early determinant in the differentiation of pathogenic Th17 cells. J. Immunol. 2011, 186, 1391-1398. [CrossRef]

27. Ali, A.; Hoeflich, K.P.; Woodgett, J.R. Glycogen synthase kinase-3: Properties, functions, and regulation. Chem. Rev. 2001, 101, 2527-2540. [CrossRef] [PubMed]

28. McAlpine, C.S.; Werstuck, G.H. Protein kinase R-like endoplasmic reticulum kinase and glycogen synthase kinase-3 $\alpha / \beta$ regulate foam cell formation. J. Lipid Res. 2014, 55, 2320-2333. [CrossRef]

29. Cross, D.A.; Alessi, D.R.; Cohen, P.; Andjelkovich, M.; Hemmings, B.A. Inhibition of glycogen synthase kinase-3 by insulin mediated by protein kinase B. Nature 1995, 378, 785-789. [CrossRef]

30. Fang, X.; Yu, S.X.; Lu, Y.; Bast, R.C.; Woodgett, J.R.; Mills, G.B. Phosphorylation and inactivation of glycogen synthase kinase 3 by protein kinase A. Proc. Natl. Acad. Sci. USA 2000, 97, 11960-11965. [CrossRef]

31. Sutherland, C.; Cohen, P. The $\alpha$-isoform of glycogen synthase kinase- 3 from rabbit skeletal muscle is inactivated by p70 S6 kinase or MAP kinase-activated protein kinase-1 in vitro. FEBS Lett. 1994, 338, 37-42. [CrossRef]

32. Stambolic, V.; Woodgett, J.R. Mitogen inactivation of glycogen synthase kinase- $3 \beta$ in intact cells via serine 9 phosphorylation. Biochem. J. 1994, 303, 701-704. [CrossRef] [PubMed]

33. Bikkavilli, R.K.; Feigin, M.E.; Malbon, C.C. p38 mitogen-activated protein kinase regulates canonical Wnt- $\beta$-catenin signaling by inactivation of GSK3ß. J. Cell Sci. 2008, 121, 3598-3607. [CrossRef] [PubMed]

34. Kaidanovich-Beilin, O.; Woodgett, J.R. GSK-3: Functional insights from cell biology and animal models. Front. Mol. Neurosci. 2011, 4, 1-25. [CrossRef] [PubMed]

35. Bhat, R.V.; Shanley, J.; Correll, M.P.; Fieles, W.E.; Keith, R.A.; Scott, C.W.; Lee, C.M. Regulation and localization of tyrosine216 phosphorylation of glycogen synthase kinase- $3 \beta$ in cellular and animal models of neuronal degeneration. Proc. Natl. Acad. Sci. USA 2000, 97, 11074-11079. [CrossRef] [PubMed]

36. Mancinelli, R.; Carpino, G.; Petrungaro, S.; Mammola, C.L.; Tomaipitinca, L.; Filippini, A.; Facchiano, A.; Ziparo, E.; Giampietri, C. Multifaceted roles of GSK-3 in cancer and autophagy-related diseases. Oxid. Med. Cell. Longev. 2017, 40, 4629495. [CrossRef]

37. Klein, P.S.; Melton, D.A. A molecular mechanism for the effect of lithium on development. Proc. Natl. Acad. Sci. USA 1996, 93, 8455-8459. [CrossRef]

38. Nikoulina, S.E.; Ciaraldi, T.P.; Mudaliar, S.; Mohideen, P.; Carter, L.; Henry, R.R. Potential role of glycogen synthase kinase-3 in skeletal muscle insulin resistance of type 2 diabetes. Diabetes 2000, 49, 263-271. [CrossRef]

39. Phiel, C.J.; Wilson, C.A.; Lee, V.M.Y.; Klein, P.S. GSK-3 $\alpha$ regulates production of Alzheimer's disease amyloid- $\beta$ peptides. Nature 2003, 423, 435-439. [CrossRef]

40. Banko, N.S.; McAlpine, C.S.; Venegas-Pino, D.E.; Raja, P.; Shi, Y.; Khan, M.I.; Werstuck, G.H. Glycogen synthase kinase $3 \alpha$ deficiency attenuates atherosclerosis and hepatic steatosis in high fat diet-fed low density lipoprotein receptor-deficient mice. Am. J. Pathol. 2014, 184, 3394-3404. [CrossRef]

41. Lawrence, T.; Natoli, G. Transcriptional regulation of macrophage polarization: Enabling diversity with identity. Nat. Rev. Immunol. 2011, 11, 750-761. [CrossRef] [PubMed]

42. Beurel, E.; Jope, R.S. Differential regulation of STAT family members by glycogen synthase kinase-3. J. Biol. Chem. 2008, 283, 21934-21944. [CrossRef]

43. McAlpine, C.S.; Huang, A.; Emdin, A.; Banko, N.S.; Beriault, D.R.; Shi, Y.; Werstuck, G.H. Deletion of myeloid GSK3 $\alpha$ attenuates atherosclerosis and promotes an M2 macrophage phenotype. Arterioscler. Thromb. Vasc. Biol. 2015, 35, 1113-1122. [CrossRef]

44. Panagi, I.; Jennings, E.; Zeng, J.; Günster, R.A.; Stones, C.D.; Mak, H.; Jin, E.; Stapels, D.A.; Subari, N.Z.; Pham, T.H.; et al. Salmonella effector SteE converts the mammalian serine/threonine kinase GSK3 into a tyrosine kinase to direct macrophage polarization. Cell Host Microbe 2020, 27, 41-53. [CrossRef]

45. Martin, M.; Rehani, K.; Jope, R.S.; Michalek, S.M. Toll-like receptor-mediated cytokine production is differentially regulated by glycogen synthase kinase 3. Nat. Immunol. 2005, 6, 777-784. [CrossRef] [PubMed] 
46. Wang, H.; Garcia, C.A.; Rehani, K.; Cekic, C.; Alard, P.; Kinane, D.F.; Mitchell, T.; Martin, M. IFN- $\beta$ production by TLR4-stimulated innate immune cells is negatively regulated by GSK3- $\beta$. J. Immunol. 2008, 181, 6797-6802. [CrossRef] [PubMed]

47. Ko, R.; Park, J.H.; Ha, H.; Choi, Y.; Lee, S.Y. Glycogen synthase kinase $3 \beta$ ubiquitination by TRAF6 regulates TLR3-mediated pro-inflammatory cytokine production. Nat. Commun. 2015, 6, 1-12. [CrossRef]

48. Hermida, M.A.; Kumar, J.D.; Leslie, N.R. GSK3 and its interactions with the PI3K/AKT/mTOR signalling network. Adv. Biol. Regul. 2017, 65, 5-15. [CrossRef]

49. Yang, H.; Ye, X.; Zhang, X.; Li, X.; Fu, Q.; Tang, Z. Intracellular osteopontin negatively regulates toll-like receptor 4-mediated inflammatory response via regulating GSK3 $\beta$ and 4EBP1 phosphorylation. Cytokine 2018, 108, 89-95. [CrossRef]

50. Ohashi, E.; Kohno, K.; Arai, N.; Harashima, A.; Ariyasu, T.; Ushio, S. Adenosine N1-Oxide Exerts Anti-inflammatory Effects through the PI3K/Akt/GSK-3 $\beta$ Signaling Pathway and Promotes Osteogenic and Adipocyte Differentiation. Biol. Pharm. Bull. 2019, 42, 968-976. [CrossRef]

51. Beurel, E.; Michalek, S.M.; Jope, R.S. Innate and adaptive immune responses regulated by glycogen synthase kinase-3 (GSK3). Trends Immunol. 2010, 31, 24-31. [CrossRef]

52. Li, L.; McBride, D.W.; Doycheva, D.; Dixon, B.J.; Krafft, P.R.; Zhang, J.H.; Tang, J. G-CSF attenuates neuroinflammation and stabilizes the blood-brain barrier via the PI3K/Akt/GSK-3 $\beta$ signaling pathway following neonatal hypoxia-ischemia in rats. Exp. Neurol. 2015, 272, 135-144. [CrossRef]

53. Park, S.H.; Park-Min, K.H.; Chen, J.; Hu, X.; Ivashkiv, L.B. Tumor necrosis factor induces GSK3 kinase-mediated cross-tolerance to endotoxin in macrophages. Nat. Immunol. 2011, 12, 607-615. [CrossRef] [PubMed]

54. Zhou, H.; Wang, H.; Ni, M.; Yue, S.; Xia, Y.; Busuttil, R.W.; Kupiec-Weglinski, J.W.; Lu, L.; Wang, X.; Zhai, Y. Glycogen synthase kinase $3 \beta$ promotes liver innate immune activation by restraining AMP-activated protein kinase activation. J. Hepatol. 2018, 69, 99-109. [CrossRef] [PubMed]

55. Kai, J.I.; Huang, W.C.; Tsai, C.C.; Chang, W.T.; Chen, C.L.; Lin, C.F. Glycogen synthase kinase-3 $\beta$ indirectly facilitates interferon- $\gamma-$ induced nuclear factor- $\mathrm{KB}$ activation and nitric oxide biosynthesis. J. Cell. Biochem. 2010, 111, 1522-1530. [CrossRef] [PubMed]

56. Guindi, C.; Cloutier, A.; Gaudreau, S.; Zerif, E.; McDonald, P.P.; Tatsiy, O.; Asselin, C.; Dupuis, G.; Gris, D.; Amrani, A. Role of the p38 MAPK/C /EBP $\beta$ pathway in the regulation of phenotype and IL-10 and IL-12 production by tolerogenic bone marrow-derived dendritic cells. Cells 2018, 7, 256. [CrossRef] [PubMed]

57. He, H.; Brenier-Pinchart, M.P.; Braun, L.; Kraut, A.; Touquet, B.; Coute, Y.; Tardieux, I.; Hakimi, M.A.; Bougdour, A. Characterization of a Toxoplasma effector uncovers an alternative GSK3/ $\beta$-catenin-regulatory pathway of inflammation. eLife 2018, 7, e39887. [CrossRef]

58. Jain, A.K.; Jaiswal, A.K. GSK-3 $\beta$ acts upstream of Fyn kinase in regulation of nuclear export and degradation of NF-E2 related factor 2. J. Biol. Chem. 2007, 282, 16502-16510. [CrossRef]

59. Kaspar, J.W.; Jaiswal, A.K. Tyrosine phosphorylation controls nuclear export of Fyn, allowing Nrf2 activation of cytoprotective gene expression. FASEB J. 2011, 25, 1076-1087. [CrossRef]

60. Kanninen, K.; White, A.R.; Koistinaho, J.; Malm, T. Targeting glycogen synthase kinase-3 $\beta$ for therapeutic benefit against oxidative stress in Alzheimer's disease: Involvement of the Nrf2-ARE Pathway. J. Alzheimers Dis. 2011, 2011, 1-9. [CrossRef]

61. Ding, L.; Yuan, X.; Yan, J.; Huang, Y.; Xu, M.; Yang, Z.; Yang, N.; Wang, M.; Zhang, C.; Zhang, L. Nrf2 exerts mixed inflammation and glucose metabolism regulatory effects on murine RAW264. 7 macrophages. Int. Immunopharmacol. 2019, 71, 198-204. [CrossRef]

62. Galván-Peña, S.; O’Neill, L.A. Metabolic reprograming in macrophage polarization. Front. Immunol. 2014, 5, 420. [PubMed]

63. Wang, R.; Xia, L.; Gabrilove, J.; Waxman, S.; Jing, Y. Downregulation of Mcl-1 through GSK-3 $\beta$ activation contributes to arsenic trioxide-induced apoptosis in acute myeloid leukemia cells. Leukemia 2013, 27, 315-324. [CrossRef]

64. Park, S.; Han, H.T.; Oh, S.S.; Kim, D.H.; Jeong, J.W.; Lee, K.W.; Kim, M.; Lim, J.S.; Cho, Y.Y.; Hwangbo, C.; et al. NDRG2 Sensitizes Myeloid Leukemia to Arsenic Trioxide via GSK3ß-NDRG2-PP2A Complex Formation. Cells 2019, 8, 495. [CrossRef]

65. Li, B.; Zhang, H.; Zeng, M.; He, W.; Li, M.; Huang, X.; Deng, D.Y.; Wu, J. Bone marrow mesenchymal stem cells protect alveolar macrophages from lipopolysaccharide-induced apoptosis partially by inhibiting the Wnt/ $\beta$-catenin pathway. Cell Biol. Int. 2015, 39, 192-200. [CrossRef] [PubMed]

66. Wang, L.; Wang, Y.; Zhang, C.; Li, J.; Meng, Y.; Dou, M.; Noguchi, C.T.; Di, L. Inhibiting glycogen synthase kinase 3 reverses obesityinduced white adipose tissue inflammation by regulating apoptosis inhibitor of macrophage/CD5L-mediated macrophage migration. Arterioscler. Thromb. Vasc. Biol. 2018, 38, 2103-2116. [CrossRef]

67. Gong, K.; Zhou, F.; Huang, H.; Gong, Y.; Zhang, L. Suppression of GSK3 $\beta$ by ERK mediates lipopolysaccharide induced cell migration in macrophage through $\beta$-catenin signaling. Protein Cell 2012, 3, 762-768. [CrossRef]

68. Rom, S.; Fan, S.; Reichenbach, N.; Dykstra, H.; Ramirez, S.H.; Persidsky, Y. Glycogen synthase kinase $3 \beta$ inhibition prevents monocyte migration across brain endothelial cells via Rac1-GTPase suppression and down-regulation of active integrin conformation. Am. J. Pathol. 2012, 181, 1414-1425. [CrossRef]

69. Zhang, L.; Wang, Y.; Xiao, F.; Wang, S.; Xing, G.; Li, Y.; Yin, X.; Lu, K.; Wei, R.; Fan, J.; et al. CKIP-1 regulates macrophage proliferation by inhibiting TRAF6-mediated Akt activation. Cell Res. 2014, 24, 742-761. [CrossRef]

70. Ha, S.D.; Ng, D.; Pelech, S.L.; Kim, S.O. Critical Role of the Phosphatidylinositol 3-Kinase/Akt/Glycogen Synthase Kinase-3 $\beta$ Signaling Pathway in Recovery from Anthrax Lethal Toxin-induced Cell Cycle Arrest and MEK Cleavage in Macrophages. J. Biol. Chem. 2007, 282, 36230-36239. [CrossRef] 
71. Song, E.Y.; Palladinetti, P.; Klamer, G.; Ko, K.H.; Lindeman, R.; O’Brien, T.A.; Dolnikov, A. Glycogen synthase kinase- $3 \beta$ inhibitors suppress leukemia cell growth. Exp. Hematol. 2010, 38, 908-921. [CrossRef]

72. Gangoiti, P.; Granado, M.H.; Wang, S.W.; Kong, J.Y.; Steinbrecher, U.P.; Gómez-Muñoz, A. Ceramide 1-phosphate stimulates macrophage proliferation through activation of the PI3-kinase/PKB, JNK and ERK1/2 pathways. Cell. Signal. 2008, 20, 726-736. [CrossRef] [PubMed]

73. Park, D.W.; Jiang, S.; Liu, Y.; Siegal, G.P.; Inoki, K.; Abraham, E.; Zmijewski, J.W. GSK3ß-dependent inhibition of AMPK potentiates activation of neutrophils and macrophages and enhances severity of acute lung injury. Am. J. Physiol. Lung Cell. Mol. 2014, 307, L735-L745. [CrossRef] [PubMed]

74. Liu, S.S.; Lv, X.X.; Liu, C.; Qi, J.; Li, Y.X.; Wei, X.P.; Li, K.; Hua, F.; Cui, B.; Zhang, X.W.; et al. Targeting degradation of the transcription factor $\mathrm{C} / \mathrm{EBP} \beta$ reduces lung fibrosis by restoring activity of the ubiquitin-editing enzyme A20 in macrophages. Immunity 2019, 51, 522-534. [CrossRef]

75. Ren, F.; Duan, Z.; Cheng, Q.; Shen, X.; Gao, F.; Bai, L.; Liu, J.; Busuttil, R.W.; Kupiec-Weglinski, J.W.; Zhai, Y. Inhibition of glycogen synthase kinase 3 beta ameliorates liver ischemia reperfusion injury by way of an interleukin-10-mediated immune regulatory mechanism. Hepatology 2011, 54, 687-696. [CrossRef]

76. Arioka, M.; Takahashi-Yanaga, F. Glycogen synthase kinase-3 inhibitor as a multi-targeting anti-rheumatoid drug. Biochem. Pharmacol. 2019, 165, 207-213. [CrossRef]

77. Kwon, Y.J.; Yoon, C.H.; Lee, S.W.; Park, Y.B.; Lee, S.K.; Park, M.C. Inhibition of glycogen synthase kinase-3 $\beta$ suppresses inflammatory responses in rheumatoid arthritis fibroblast-like synoviocytes and collagen-induced arthritis. Jt. Bone Spine 2014, 81, 240-246. [CrossRef]

78. Wagner, F.F.; Benajiba, L.; Campbell, A.J.; Weïwer, M.; Sacher, J.R.; Gale, J.P.; Ross, L.; Puissant, A.; Alexe, G.; Conway, A.; et al. Exploiting an Asp-Glu "switch" in glycogen synthase kinase 3 to design paralog-selective inhibitors for use in acute myeloid leukemia. Sci. Transl. Med. 2018, 10, 431. [CrossRef]

79. ClinicalTrials.gov. Available online: https://clinicaltrials.gov/ (accessed on 18 February 2021). 